\title{
THE VITAL FORCES OF SOUTHERN BUDDHISM IN RELATION TO THE GOSPEL
}

\section{IN GEYLON}

For over two thousand years Ceylon has been a kind of 'theocracy without a God,' a kingdom whose history is the history of a religion and whose kings are largely overshadowed by a vast and powerful community of celibate monks. For the 7774 Bhikkhus who to-day wear the yellow robe are representatives, through an unbroken succession, of the good and gentle Prince Mahinda, a son of Asoka the Great, who about 250 B.c. introduced the religion of Gautama Buddha into Ceylon; and the books they so carefully preserve are believed to contain the exact words of the founder and of his immediate followers. It is therefore claimed that in Ceylon Buddhism retains its pristine purity ; and it is certainly true to say that in Ceylon it has had a unique chance of almost unhindered growth, for it has been smiled upon by every king since Tissa in the third century B.c. made it the national religion. Ceylon has therefore been a laboratory in which the power of Buddhism as a nation-building religion has been fairly tested, and in which the principle of monasticism has had every opportunity of vindicating itself.

In studying the vital forces of Buddhism in Ceylon, we have clearly to separate the Sangha, the celibate monks, from the rest of the people: for Buddhism frankly divides human society into those two great classes-the inner circle of the initiated, specialists in the spiritual life, and the great mass of the people who can hardly hope to make the same 
progress in the things of the spirit. It will be well, therefore, if we attempt to set over against one another two typical scenes illustrating in an impressionist and symbolical way the two spheres of Buddhist life in Ceylon : and these will serve as an introduction to an atmosphere morally and intellectually strange to western minds.

\section{II}

We pass by winding paths and steep flights of rock-hewn steps into the peaceful fragrant courtyard of a Buddhist Vihāra. At once we are in an atmosphere remote from the world : hardly a sound breaks the heavy stillness, except when the lcaves of the great Bo-tree rustle in the breeze, or the plaintive ' other-worldly' chant of the Buddhist Slokas reaches us from the Pansala or dwelling-place of the Bhikkhus. Before us stretches a wonderful panorama of paddy-fields and cocoanut estates, green in the foreground and passing into opalescent blues and greys in the distance, and beyond are blue hills and the great peak of Srippāda, the sacred mountain of Buddhism, where is a colossal footprint of the Buddha, reverenced and even worshipped by countless thousands, and visited every year by many a white-robed company of pilgrims. Behind is the rock-hewn shrine, dark and mysterious, in which reposes a colossal image of the Buddha, a symbol of calm meditation and kindliness which epitomizes the Buddhist ideal of character. A yellow-robed Bhikkhu comes forward gravely and ushers us into the shrine, and there is ample time to note his keen and stoical face and his bearing of conscious dignity. Do the broad acres below not belong to his Vihăra, and is he not the spiritual lord of all the countryside and an able scholar of the Pali books? His companion is younger and stouter, heavy-jowled and stupid in expression, clearly a villager who has taken the yellow robe rather from force of circumstance than because of any call to the office; he knows little of the books or of the history of the place.

But it is well worth study, and the elder Bhikkhu is able 
to explain its frescoes, pictures of the legendary lives of Gautama, his former existences in many an animal form, his sacrifices of himself for others, his 'incarnation' as Vessantara the Prince who gave wife and children to a hunch-backed Brahmin, his miraculous birth as the Buddha, his renunciation of home and wealth, his enlightenment and his labours as a preacher, and lastly his attainment of Nirvāna, the Great Peace. All this is recorded in red and yellow mural paintings; and here too is Ananda his personal attendant, and Maitri or Metteyya, the coming Buddha who in the distant future shall revive the religion and carry on his work.

Here too are pictures which have an even more vital meaning to the great bulk of the pilgrims who visit the shrine; pictures, as the younger monk smilingly explains, of the tortures of the wicked in their next birth : and when the people have knelt before the Bo tree and offered their candles and their flowers in the shrine, the parents will explain them to the children, not failing to point the moral : here is a liar whose tongue is being torn out with red-hot pincers; here a low-caste mar is being crushed under great rocks for speaking rudely to a feudal superior; here the unfaithful wife is climbing a tree of jagged spikes whilst demon-torturers thrust her through with tridents and spears.

By the portals of the shrine stand figures of Hindu godsSakra and Vishnu-humble attendants upon the Buddha within : is he not greater than any god?

With all its quiet and its solemnity there is something monstrous about this cavern-shrine and we are glad to escape from the heavy damp air, impregnated with the odour of bats and tallow-candles, of camphor and jasmine and frangipani, and to pass into the village street below, where are bustle and life and the normal activities of man.

Let us accompany the Bhikkhu on his begging round. As he stands silent with downcast eyes before each house the men stare stolidly at him : they do not love him and his Order though they respect his cloth and tacitly accept the teaching that the Sangha is the harvest-field of merit. But 
the women are more faithful-or more credulous-and his bowl is well filled with rice and curry and plantains. These he accepts with no word of thanks : and no request passes his lips: does he not confer a favour upon the faithful donor? So we leave him, silent, aloof and a little proud, a drone in practice if not in theory, who later will repay their alms by reciting unintelligible passages from the Pali books, or chanting Pirit to drive out a snake or a demon. Here his pastoral duties end, and for the rest he is conning the sacred books and possibly giving fitful instruction in Sinhalese reading and writing to a handful of village children.

What do they and their parents know of Buddhism? They all know the meaning of karma and transmigration, and the idea of merit is deeply ingrained in them. The five precepts-to abstain from killing, adultery, lying, and stealing and to take no strong drink-they also know, and something, often very vague, of the life-story of the Buddha; but the practice of meditation and the goal Nirvana-these are not for them. To be re-born to a happy human life or to become a deva or god-this is their ambition, as indeed it is the ambition of the vast bulk of the Bhikkhus. The intellectual and moral atmosphere of the lives of the poorer class of Ceylon villager has been admirably suggested in a penportrait by Mr. L. S. Woolf : ' It was a strange world, a world of bare and brutal facts, of superstition, of grotesque imagination ; a world of trees and the perpetual twilight of their shade ; a world of hunger and fear and devils, where a man was helpless before the unseen and unintelligible forces surrounding him.' 1

And this world of demonism is inextricably blended with the life of even the more intelligent villagers : with it Buddhism has entered into an unholy alliance.

To express something of what this Buddhism of the majority of Ceylon Buddhists stands for, I may be allowed to quote an account $I$ have given elsewhere of what happens whon a villager falls sick, for it epitomizes much of the 


\section{strange medley which holds the allegiance of three-fourths of the Sinhalese.}

Kalu Banda falls sick; his wife calls in the wedaräla, or native doctor, and goes to the temple (if she be an unusually devout Buddhist) with an offering of flowers. The medarāla prescribes a concoction of herbs; and if the case is a difficult one, advises that the astrologer be also consulted. (Many wedarälas are themselves astrologers, and a few combine a considerable knowledge of western science with implicit belief in the influence of the stars upon human destiny, or again an astrologer may be also a Buddhist Bhikkhu). Kalu Banda's wife goes to the astrologer armed with his horoscope; and from this he tells her the nature of the disease and advises her as to its treatment. Meantime the family are busy with their own diagnosis. 'It must be a demon,' says his daughter, 'Or a star,' says his mother-in-law. 'It is my karma anyhow,' says the patient, 'If I get well within a week I vow one hundred candles at the Kelani Temple' (or at Adam's Peak). The wife now arrives bringing the advice of the astrologer, and calls in either the kattadiya (devil-dancer and enchanter) or the Buddhist Bhikkhus. The former examines the patient; if he has a headache or any other nervous ailment, he uses charms which often prove efficacious ; if it is some other trouble, a devil-dance is begun and carried on with great vigour. If it is the Bhikkhus who are called in, they recite Pirit, the orthodox ceremony for such cases. This may prove effectual, for the people look upon it as magic and their implicit faith is a potent thing; in a few cases it actually replaces evil influences in the mind by good ones, fixing the attention of the patient upon the Buddha rather than upon himself. In neuropathic cases it is especially effectual; yet most Buddhists resort to it only after they have tried other means.

But supposing Kalu Banda has some infectious illness the treatment is quite different. Such epidemics as small-pox or chicken-pox are supposed to be in the control of the goddess Pattini, and it is the kapurāla, or priest, who is called in in such cases. He will pray to the goddess, or advise that some ceremony be performed to appease the particular demon; or he will offer a goat or a fowl.

How real a grip these lemons have on the people may be estimated by the following well-attested facts. Until lately there lived in Kandy an old woman who had escaped with her life after being offered to the local demon(Bahirawa Yakshya). Every year a young virgin was bound to a stake on Bahira Kanda and left for a whole night. As a rule these girls died of fear. But this one escaped, because her lover spent the night with her and cheered her during this ordeal, a very terrible one to a Sinhalese woman. A grandfather, on seeing that his daughter had brought forth a child with teeth and hair already grown, smashed its head crying, 'It is a devil.'

With such degrading superstitions has Buddhism formed an unholy alliance. Even an orthodox Buddhist will do meritorious actions to appease demons; he will invoke the demon in the name of the Buddha, or will make 
an offering in the temple, to gain merit for himself and for the demon who is also in the clutches of karms.

But to return to Kalu Banda. All these varied methods have failed; the demon is not to be appeased. So the trump-card is played. The patient pretends to die; and the family even go through a mock funeral ceremony. The demon is perhaps a fool, and will now go away satisfied that he has wreaked full vengeance upon his victim. ${ }^{1}$

Such then are the two spheres of Buddhism in Ceylonthe Bhikkhu to meditate, the layman to toil and suffer until he too realizes that all is sorrow and enters upon the life of the recluse. Then he will at any rate have his feet set upon the lowest rung of the ladder of Nirvāna. What are the vital forces of this religion, which still, in the words of the Census Report of 1911, "has an enormous hold upon a very large proportion of the people of Ceylon'?

\section{III}

1. First, we should, I think, place the very strong hold which the doctrines of karma and transmigration have laid upon their intellects. They are as saturated with these ideas as are Mohammedans with that of the will of Allah, or Christians with that of the forgiveness of sins. The doctrine of karmathat ' what we have been makes us what we are'-is 'the very taproot of all their religious thinking'; 'it satisfies them more than anything we can say,' as two of my correspondents have expressed it. Moreover, it has very considerable influence upon their characters, making them fatalistic indeed, but also acting to some extent as a deterrent power. There are practically no signs that this doctrine, which accounts very mathematically for inequalities of lot and is receiving support from scientific thinkers in the West, is losing its hold upon them; and in so far as it contains a great truth Christian preachers may find in it a very important point of contact : they should very carefully avoid loose

\footnotetext{
${ }^{1}$ Quoted from Buddhist Ideals (Christian Literature Society for India). Appendix A, pp. $147-9$.
} 
statements of the meaning of forgiveness. The taunt of Antinomianism is frequently hurled at Christianity by Buddhists.

Yet the doctrine of transmigration is so closely bound up with the doctrine of karma that it may well be that the former must first be replaced before the truths contained in the latter can be preserved. And it cannot be eradicated by argument : it can only be superseded by a doctrine more congenial to human hearts. There are signs that the Buddhist in his longing for family reunion after death is really dissatisfied with a doctrine which makes such reunion well-nigh impossible, and there is such very slender evidence for the doctrine that it is extraordinary how persistent is the belief in it. Moreover, the conception of karma has become degenerate and is working great havoc in what was once a lofty ethical system, for it works out in practice as a mere system of merit. Kusal-merit, and Akusal-demerit, take the place of righteousness and sin, and the ethical ideas of modern Buddhists are almost purely utilitarian. A thing is wrong because it produces bad effects : and inasmuch as it can be counteracted by a deed in the opposite direction, a meritorious deed, it does not very much matter after all.

Buddhism has in fact 'out-Tetzeled Tetzel' in the extreme lengths to which it has carried this doctrine. In practice the attempt to gain merit and to counteract demerit is the central thing in modern Buddhism in the south, for it is apparently just and is so simple that the merest villager can understand it, and the Bhikkhus in sermon and conversation have a tendency to come back with unction to this point. This and ' not killing' are almost their only themes. What wonder that the Sangha now own one-third of the cultivated land of Ceylon, for to give to them is more meritorious than to help the sick or even to go on pilgrimage. It is explicitly stated in the books that making gifts to the Sangha is the chief duty of the layman. This has now gone so far that the people are beginning to revolt against it and it may be that some Buddhist Luther will arise and strive to cleanse 
Buddhism-but in that case the books will be against him and he will get short shrift. In Burma the Paramat sect has been very fiercely persecuted for such a revolt (pace those western enthusiasts who claim that Buddhist $:$ never persecute).

Yet there are not wanting germs of a nobler doctrine : e.g., the belief that a man's dying thoughts greatly affect his future destiny, for they are the expression of his character. And Buddhism is struggling towards a doctrine, half-expressed in the books, that it is what a man is that matters, not what he gives or does.

Another germ of a loftier doctrine-one which may surely be made to germinate by Christian preachers-is the idea of ' reversible merit.' This teaches that the merit a man acquires may be shared with others : a woman will carry her infant child up the steep slopes of Adam's Peak or through the scorching jungle roads to Anuradhapura that he may share her merit : or a sick man will offer his gift and ejaculate 'May the merit of this offering be shared with the demon who is hurting me, or with the company assembled.' When King Edward VII died, the poor of Ceylon were fed by the richer Buddhists that the King might receive the merit so acquired to help him in the next life.

Here are attempts $(a)$ to get away from mathematical conceptions; (b) to socialize the individualistic spirit of Buddhism; the Christian preacher should note these implicit criticisms of the doctrine of karma.

But far more important and beautiful is the Buddhist conception of the store of merit acquired during numberless lives of sacrifice by the Buddha :

More than the ocean is the blood he shed,

More than the stars of heaven the eyes he gave.

And this store is a kind of bank upon which the faithful may draw : the Buddhist knows something of being 'accepted in the Beloved,' and a very exnerienced and wise Sinhalese pastor tells me he has found this a most useful point of con- 
tact. It is recorded that King Ajātasatru escaped the consequences of the awful sin of parricide becaust of his devotion to the Blessed One : and from such germs Northern Buddhism has developed its doctrine of salvation by faith in Amida Buddha. Southern Buddhists, as Christian influence spreads, are tending in the same direction, and I have been rebuked by Buddhists both in Ceylon and Burma for saying that Buddhism in these lands knows nothing of a saviour.

Here then is a point of contact for preaching the atoning work of Christ; and I would suggest that this work be shown to be a continuous process; that whilst it is true to say 'Christ died for me' it is also true to say ' God is always suffering for my vin.' For the Buddhist thinks Jovingly of an age-long act or series of acts of self-sacrifice, and is apt to set over against the death of Christ a series of such sacrificial lives and deaths-mythical for the most part, yet very real to him.

2. Next to the doctrine of karma and of merit, therefore, should be laced the 'fact of Gautama.' The Sinhalese child grows up with images of the Buddha-from vast rockliewn colossi down to tiny household images of brass-constantly before him : some are meditating, some teaching, and all look bencvolent and calm. The impression made is lecp and lasting, and nothing will ever eradicate it. Moreover there is a great revival of Buddhist enthusiasm for pictures and images; gajly colouled imitations of Christian art are now found in many houses; sometimes it is 'Queen Maya' with the infant Buddha, and at others Gautama preaching with his disciples grouped round him.

Carols such as the following are regularly sung at the Wesak festival, corresponding to our Christmas :

$$
\begin{aligned}
& \text { Glory, land, and honour } \\
& \text { To our Lord the King; } \\
& \text { 'This throngh comntless ages } \\
& \text { Men and derws sing. }
\end{aligned}
$$

And in his enthusiasm the Buddhist forgets that the 'Lord' is inaccessible and unapproachable and thinks of him as alive 
and ready to help : gratitude to the Buddha is a genuine religious motive in Ceylon.

I have seen a transparency inscribed ' Long Live George V, King and Emperor by grace of the Triple Gem ' in which the Buddha, the Order and the Law are personified and made into a kind of Providence. The ideal figure in the hearts of the laymen is different from that in the thought of the Bhikkhus: he is not the wandering ascetic teacher but a glorified prince, laying down crown and sceptre for their sakes. In other words, they are tending to think of him more as Christians think of Christ : or as the Northern Buddhists think of the historical Buddha- who for their sakes became poor,' not merely for his own salvation.

For the great majority he is even more; he is God. The instincts of the human heart are not to be denied : it cannot rest content with a stoical agnosticism. They look very wistfully, too, to a coming Buddha, and the father will bless his child saying, ' May you be reborn when Maitri comes and attain the Great Peace.' The learned Buddhist denies that there is anything of worship here, yet the following extract from the Ceylon Census of 1911 will show how ready the villagers of Ceylon (nine-tenths of the population) are to make gods of less worthy claimants to the honour than the great prophet of Asia.

The worship of the hero becomes the cult of a new god. There are many such instances in Ceylon. King Raja Sinha I was deified. . . . Keppitipola Disawa of Uva, executed for rebellion in 1818, is worshipped in Uda Dumbara . . . and Kiwalegedara Mohottala, hanged for the same offence, is worshipped . . . as a devil. . . . Famous Portuguese leaders . . . were even made divinities. When the statue of Sir Edward Barnes was erected ... it was necessary to fence it with an iron railing on account of the crowd of pilgrims who made offerings round the pedestal of the statue."

It would seem as if the Sinhalese Buddhist is longing for an object of worship, and if we can succeed in giving him a vision of an eastern Christ, with the calmness and majesty of the Buddha and with a more constraining love, he will surely become a very devout and passionate Christian.

\footnotetext{
${ }^{1}$ Fifty $Y_{\text {cars }}$ in $C_{c y l o n,}$ Major Skinner.
} 
3. Perhaps we may place next amongst the vital forces of Ceylon Buddhism its strong pictorial appeal to the imagination. It is indeed beautiful and stirring : the torchlight-processions, the yellow-robed Bhikkhus, the exquisite sites of its temples, its happy parties of pilgrims and its other social festivities-all these charm the eye and captivate the imagination. European 'Buddhists' like Fielding Hall and Lafcadio Hearn have been ' converted' largely, I believe, because of this aesthetic appeal, and the young Buddhist grows up in the midst of sights and sounds which fascinate, for the sonorous reading of the books and the weird melancholy of pipes and tomtoms also play a large part in the sensuous appeal.

It is, I think, true to say that it is these things which make young Buddhists keen on their religion, for children are very largely creatures of imagination: and the Christian Church must surely see to it that its social and festive and pictorial appeal is strengthened. We need in the mission field a Christian artist who shall be a kind of blend of Mr. Louis Parker and Mr. Rabindranath Tagore, to plan and carry out Christian festivals. At present Christianity seems sad and a little dull by contrast with Buddhism, whereas the religion of resurrection is far gladder and infinitely more romantic than that of release.

Moreover these shows and processions are specially dear to Buddhists in Ceylon, for they are remnants of their old feudal splendour, of the great days of the Buddhist kings, and they serve to hide the fact that the Buddhism of to-day is lacking in the forces of cohesion and in the solidarity which could make it once more a national religion.

If one wishes to see the Sinhalese schoolboy at his best, one should watch him at the annual Perahera in Kandy, which is a thing of pomp and beauty with its slow-moving elephants in scarlet and gold, its weird torchlight and fantastic dances, and the wild melancholy of its barbaric music. The Kandyan boy will gaze at this spell-bound, his eye kindling and his chest swelling with pride in this epitome of a 
civilization which is passing away, but is still very dear. And to become a Christian means to give up all personal share in this and much else, to lose his feudal position, to sacrifice the rich perquisites of the temple trusteeship, hardest of all, to be called renegade and traitor by one's nearest and dearest : ' except a man take up his cross daily.' . . . Yet the young Kandyans, knowing all this, are being compelled by the appeal of a higher beauty and a deeper allegiance. Will all who persevere so far in this article pray for a mass movement amongst these sons of the hills in whom a romantic and passionate nature promises rich soil for the fruits of Christian character ? Even as I write comes the news of the baptism of four of the most promising of them, and during the past five years some twenty-five have been baptized at Trinity College, Kandy.

4. The fact, then, that Buddhism is the national religion, the religion of over 2000 years in the country's history, this is another vital force in Ceylon Buddhism. For it was Buddhism which built their ancient cities and gave them their literature. Conservatism, therefore, and pride of race are fighting on behalf of Buddhism, and it remains for Christian preachers and writers to prove that the Gospel is the fulfilment of the law of Gautama no less than of that of Moses, and that their national aspirations will find fullest and freest expression in a modern state such as Christianity alone can construct. At present Christianity wears a western dress and the Buddhist revival is very largely anti-western : its moving spirits, the late Mr. Harichandra and Mr. Dharmapala, have used the nationalist weapon to smite Christianity-and in so far as the government of the country remains largely unchristian in its system of taxation and in its fostering of the traffic in intoxicants, the arguments used are very powerful. These agitators are often very intemperate, but some of their grievances are real enough : and till these be removed the kingdom of God is greatly hampered.

5. Connected with this nationalist enthusiasm is the erroneous notion widespread amongst Buddhists that Chris- 
tianity encourages drunkenness-a pathetic comment upon our western civilization. We have several times been told by Buddhist parents, ' Yes, you may make my boy a Christian if you will not teach him to drink.'

Akin to this feeling and even more vital is the emphasis Buddhism lays upon 'not killing,' and the horror with which strict Buddhists look upon our laxity in this matter. No one who has not lived in a Buddhist land can realize how great a part this idea plays in modern Buddhism. The ethics of Gautama Buddha, as the people know them, are almost summed up in these two words. The Christian sojourner in those lands will do well to take no life wantonly, but there is much to be said on both sides, ${ }^{1}$ and it is a striking fact that Christianity has made by far the most satisfactory progress both extensively and intensively amongst the fisher-caste, who for their occupation are looked at askance by Buddhism : they are the wealthiest and most progressive of the Sinhalese, and are noted for their generosity to good causes.

6. These precepts, 'Do not kill; do not drink strong drink,' are part of the Pancha Sila or five precepts, and the remaining three, 'Do not commit adultery; do not steal ; do not lie,' are equally well known if not so much emphasized. Other parts of the moral teaching of Gautama are familiar to the people, all of whom know the summary, 'Do good ; cease from evil; cleanse your minds'; and these ideals must be reckoned as amongst the living forces of Buddhism. So must the great love of the people for kindliness and compassion. 'He is a very kind man' is equivalent to 'he is very good.' Perhaps kindliness is the most Christlike thing in modern Buddhism.

7. Last but not least is the far-off vision of one who shall give them power and strength to bridge the gulf between knowing and doing. Till Maitri (to whom we have already referred) shall come, Ceylon Buddhists-Bhikkhu and layman alike-confess that they have no spirit to live up to the difficult moral ideal set before them, still less to follow those

'A scholarly and kindly tract dealing with the ethics of the subject is much needed. 
mystical practices of meditation which are said to lead on to Nirvāna and which are the very kernel of Buddhism. As one of Bishop Copleston's correspondents put it, 'These things are very non-existent.' All would-be reformers acknowledge and bewail this fact, and even the late Venerable Sri Sumangala, who was cremated with almost royal honours, was held by Buddhists to have not yet entered the path to emancipation-Sowan. The Bhikkhus one and all maintain that it is impossible now to reach Nirvāna, for the religion has entered upon a stage of degeneration, foretold as they believe by Gautama Buddha himself, when such attainment is no longer possible. 'We are walking in darkness,' said a Buddhist leader in Ceylon, ' without seeing a light, a person or a hope.' 'Nirvāna,' said a Burman Bhikkhu, ' is a fearsome thought; I have no hope of attaining it.'

\section{IV}

We come then to the striking fact that whilst Ceylon Buddhism has vital forces of great power yet here at the very heart of it is decay and death. And in the concluding section we may attempt to show how the vital forces of the Gospel may triumph where Buddhism has failed.

(1) In the first place, it is clear that whilst Nirvāna is a vague and ill-defined and unattainable ideal, the Christian heaven, if it be adequately preached, cannot fail to attract their hearts and to appeal to their reasons. They are already convinced that life in a heaven is a reality attainable by the good man : and they long to be assured of the possibility of reunion with their dear ones. According to Buddhism, this is only a bare possibility and can at best be but a temporary joy; if the karma of the persons is identical, they will be reborn under similar conditions, possibly in the same family.

There are signs of considerable syncretism in the view of heaven commonly held : the earnest Buddhist knows that his religion teaches something different from his ideal, yet he hopes that for him some exceptional good fortune is in 
store : or he naïvely superimposes Christian ideas upon the Buddhist doctrine.

As in the days of the early Church the preaching of the resurrection was strange and bewildering yet very powerful in its appeal, so it is in Buddhist lands to-day if the preaching be really triumphant and joyous. It seems that we must first ourselves recover the rapture and glamour of that early Easter faith if we are to convince others of its truth : and there is a tendency to preach the cross too exclusively. Our preachers sometimes seem almost to forget that without the resurrection the cross is a meaningless tragedy, and that in the preaching of the atonement the resurrection plays a vital part. Thus the only way of undermining the doctrine of transmigration is being neglected, and Christianity seems a sad religion and not one of joy. Without the resurrection it is almost as pessimistic as Buddhism without Nirvāna-and one pessimism is not likely to replace another. Our clergy in Ceylon should, I think, avoid the hideous black hat and clothes which have somehow got associated with religion in the West (and which suggest bad luck to the Sinhalese), and our funerals are too often very pagan manifestations of hopeless grief.

(2) As with Nirvāna so with the method of attaining it. The practice of meditation, which is the very kernel of Buddhism, is almost a dead letter in Ceylon : and the people want something to put in its place. They do in fact pray whether they will acknowledge it or not. One may see them kneeling abstracted and devout in front of the Bo tree, and praying for material benefits in this world (though this is not orthodox), or that they may be reborn to see Maitri Buddha and attain Nirvãna. But they do not claim that their prayers are answered. Now Christianity is essentially the religion of prayer, and it is often the fact of answered prayer that brings Buddhists to Christ. We must fearlessly preach the efficacy of prayer, and use it over the sick. The Church needs to recapture the secret of prevailing prayer : all that is needed to replace Buddhism is vital Christianity. 
For if prayer be efficacious, then karma must go: if things can be got by asking the world is not merely a closed system of rigid natural law.

(3) Connected with prayer is the mysticism essential to Christianity. Communion with the living Christ-this surely may be offered very definitely in place of the far-off hope of the coming Buddha. Buddhists listen reverently and attentively to such preaching and the wistfulness of some of their faces is very touching. Their dim half-formulated conceptions of a creator and a providence predispose the more thoughtful of them to listen to preaching about the majesty and power and love of God: Christ should be preached, we believe, as the incarnate God revealing by His miracles and death and resurrection God's power and justice. and love, rather than as Son of God-for they have very materialistic ideas of fatherhood.

(4) Moreover, just as He found acceptance in Galilee and in the Roman Empire as the Saviour from the powers of darkness, so to the demon-haunted villagers of Ceylon He should be proved to have still His ancient power. The Roman Church is wise in the use of exorcism, for the Sangha owes much of its influence to its performance of $P$ irit : a ceremony to some extent suceessful in neurotic cases.

These four points may be summarized by saying that Christianity is a vital religion in proportion as it is miraculous : and only in so far as it is vital can it hope to replace a religion so strong as Buddhism. It is not an ethical system that Buddhists want, for that they already possess : it is a living vital power for conquest and victory-victory over death and sin and the fear of demons and the power of circumstance. Such are the implications of the doctrine of the Fatherhood of God; His kingdom is the kingdom not merely of law but of grace.

(5) Yet our preaching needs to be thoroughly ethical : a loose doctrine of forgiveness causes the Buddhist to scoff, and careful training is much needed in the best thought upon the atonement and the true meaning of the forgiveness of sin. 
It seems likely that these doctrines will gradually win a place first by linking themselves with the doctrine of karma (counteractive karma being an accepted idea) and later by disintegrating it.

(6) Again, if $\mathrm{Cl}$ nistianity is indeed a life, it will manifest itself in social service: it will prove itself to be not a denationalizing and disintegrating force but a nation-building power. The great doctrine of the brotherhood of man is accepted by Buddhists but not much practised. Christianity alone has a sufficiently constraining motive, for it sees in the leper and the outcast a brother 'for whom Christ died.' Works of healing are an essential part of the gospel message and yet Ceylon has at present no medical mission. The work lately started for the deaf and blind is already proving a valuable bit of apologetic, and the wonderfully courageous purity campaign just carried out in Colombo has also given the Buddhists furiously to think; whilst sucı practical social Christianity as the corporate life of the mission schools and of the Y.M.C.A. (which is rapidly becoming indigenous) do much to convince Buddhists that Christianity has forces of cohesion which are not found in Buddhism. The fact, moreover, that Christian efforts are sustained and progressive makes Buddhists realize that they are lacking in something that makes for united and long-sustained effort. We believe that the admirable training colony scheme for which Mr. A. G. Fraser is collecting funds will provide a much-needed centre for building up an efficient native ministry and therefore an indigenous Clurch. Every year the number of learned Bhikkhus is increasing owing to good work done in the Vidhodaya College in Colombo; and the Christian Church needs leaders still better trained, trained not only in theology, but in such practical things as will make them social as well as religious leaders. For the Sinhalese villagers are in desperate need of shepherds : debt, disease, superstitions, fear and crass ignorance are preying upon them, and the Christian catechist, if he be a leader trained in the elements of medicine and of agriculture, will do much to 
save these perishing masses, and to prove that Christ gives abundant life.

(7) Once more, the Christian community of Ceylon number ten per cent of the total population, a very high proportion compared with India, and if they be really living Christians then the victory is assured : to vitalize the Christian community, and to send out leaders with a living experiencethis must be the first task of the Church in Ceylon.

In a word, no amount of logic and skill in preaching can succeed without the constraining presence of the Holy Spirit, for Buddhists are hungry for those more spiritual elements of religious experience which are His alone to give : and a hundred years of very indifferent success makes the Church herself long for a great revival of spiritual power and a living experience of the presence of her Lord, of victory in prayer, of power to heal and save.

Buddhism may well prove a schoolmaster to bring men to Christ if the Christianity presented to its followers be not another law nor another philosophy-but a life. 'For the kingdom of God is not ir word, but in puwe'

Kennetil J. Saunders 